\title{
Identification of longitudinally dynamic biomarkers in Alzheimer's disease cerebrospinal fluid by targeted proteomics
}

\author{
Kristin R Wildsmith ${ }^{1 *}$, Stephen P Schauer ${ }^{1}$, Ashley M Smith ${ }^{1}$, David Arnott ${ }^{2}$, Yuda Zhu ${ }^{3}$, Joshua Haznedar ${ }^{4}$,
} Surinder Kaur ${ }^{5}$, W Rodney Mathews ${ }^{1}$ and Lee A Honigberg ${ }^{1}$

\begin{abstract}
Background: Alzheimer's disease (AD) is the leading cause of dementia affecting greater than 26 million people worldwide. Although cerebrospinal fluid (CSF) levels of $A \beta_{42}$, tau, and $p$-tau ${ }_{181}$ are well established as diagnostic biomarkers of $A D$, there is a need for additional CSF biomarkers of neuronal function that continue to change during disease progression and could be used as pharmacodynamic measures in clinical trials. Multiple proteomic discovery experiments have reported a range of CSF biomarkers that differ between AD and control subjects. These potential biomarkers represent multiple aspects of the disease pathology. The performance of these markers has not been compared with each other, and their performance has not been evaluated longitudinally.
\end{abstract}

Results: We developed a targeted-proteomic, multiple reaction monitoring (MRM) assay for the absolute quantitation of 39 peptides corresponding to 30 proteins. We evaluated the candidate biomarkers in longitudinal CSF samples collected from aged, cognitively-normal control $(n=10), M C l(n=5)$, and AD $(n=45)$ individuals (age $>60$ years). We evaluated each biomarker for diagnostic sensitivity, longitudinal consistency, and compared with CSF A $\beta_{42}$, tau, and p-tau ${ }_{181}$. Four of 28 quantifiable CSF proteins were significantly different between aged, cognitively-normal controls and AD subjects including chitinase-3-like protein 1, reproducing published results. Four CSF markers demonstrated significant longitudinal change in AD: Amyloid precursor protein, Neuronal pentraxin receptor, NrCAM and Chromogranin A. Robust correlations were observed within some subgroups of proteins including the potential disease progression markers.

Conclusion: Using a targeted proteomics approach, we confirmed previous findings for a subset of markers, defined longitudinal performance of our panel of markers, and established a flexible proteomics method for robust multiplexed analyses.

Keywords: Alzheimer's disease, Cerebrospinal fluid, Biomarkers, Mass spectrometry, LC-MS, Targeted-proteomics, Multiple-reaction monitoring

\section{Background}

Alzheimer's disease (AD) is the most common form of dementia and the $6^{\text {th }}$ leading cause of death in America [1]. The pathological hallmarks of $\mathrm{AD}$ are extracellular plaques composed of amyloid beta $(\mathrm{A} \beta)$ and neurofibrillary tangles composed of hyperphosphorylated tau (p-tau). Reductions in cerebrospinal fluid (CSF) $\mathrm{A} \beta_{42}$ and increases

\footnotetext{
* Correspondence: wildsmith.kristin@gene.com

'Department of Phamacodynamic Biomarkers within Development Sciences, Genentech, Inc. (a member of the Roche Group), 1 DNA Way, South San Francisco, CA 94080, USA

Full list of author information is available at the end of the article
}

of CSF tau and p-tau ${ }_{181}$ are observed in AD patients in comparison with aged, cognitively-normal individuals, and these changes in CSF correlate with the pathological hallmarks of $\mathrm{AD}[2,3]$. The change in levels of $\mathrm{A} \beta_{42}$ and tau begin 1-2 decades prior to onset of symptoms, with the change in $\mathrm{A} \beta_{42}$ preceding that of tau $[4,5]$.

CSF $A \beta_{42}$, tau and $p$-tau ${ }_{181}$ are routinely used in $A D$ research and drug development. However, while the rank order performance (relative quantitation) of these biomarkers has been consistent, the inter-laboratory variability in the absolute value has been high [6-8]. In 
addition to variable performance, there is significant overlap between levels in controls and AD patients. Further, none of the three established CSF biomarkers have been directly linked to efficacy in a clinical trial. For example, while CSF levels of tau and p-tau ${ }_{181}$ levels did trend toward decline after treatment with bapineuzumab, no correlation with cognitive benefit was observed (reviewed in [9]).

There is a need to develop additional biomarkers that can aid in the diagnosis and treatment of AD. Many proteomic studies have identified potential AD biomarkers (reviewed by $[10,11]$ ), generating a substantial list of candidates that need to be evaluated for their utility. However, follow-up studies focusing on individual candidates are limited and usually focused on markers for which existing immunoassays are available. The development time for a new immunoassay can be significant and relies on successful identification of specific and high affinity antibodies. Targeted-proteomics is an emerging tool to accelerate hypothesis driven biomarker assay development by enabling the quantitative assessment of potentially hundreds of biomarkers simultaneously (reviewed in [12-14]).

Candidate AD biomarkers in CSF were selected based upon the consistency of their identification in proteomic discovery experiments [15-23]. These experiments used many different proteomic approaches, including differences in sample preparation (in-gel vs. in-solution digestion), the mass spectrometer (MS) used for analysis (MALD-ToF vs. FT-ICR), and the quantitation technique (label-free vs. iTRAQ). The differences in the proteomic techniques may account for some discrepancies in the trend of change observed for certain markers, but more importantly highlight the need for targeted-follow-up of candidate biomarkers within a single sample set. Independent of the proteomic experiments, additional candidate biomarkers were selected for evaluation based on their known relationship with AD (e.g. apolipoprotein E4) [24], or their emerging promise as disease progression markers (ex. Visinin-like-protein 1) [25,26].

A multiplexed, absolute quantitative LC-MS/MS multiple reaction monitoring (MRM) assay was developed to quantitate candidate biomarker-specific peptides in CSF samples from cognitively-normal, aged control, mildly-cognitively impaired (MCI) and $\mathrm{AD}$ patients. We evaluated the diagnostic utility of all the protein-specific peptides in comparison with the published proteomic literature and also compared with the classic AD CSF biomarkers $A \beta_{42}$, tau and p-tau. The longitudinal performance of each biomarker (sampled serially from the same patient) was established, with the majority of peptides demonstrating stability over the course of a year. Four candidates decreased over time in $\mathrm{AD}$ patients. Results from this targeted-proteomic assay narrow the list of candidates for more rigorous follow-up and increase the rate of development of novel clinical biomarkers for AD.

\section{Results}

\section{CSF biomarker MRM panel development}

Based on a review of the CSF discovery proteomics and biomarker literature, initially 50 candidate biomarkers were selected for evaluation. Of these, 30 proteins were detectable in pooled cynomolgus monkey and pooled human CSF (from young-cognitively normal control and Alzheimer's subjects) by a high resolution LTQ-orbitrap MS operating in unbiased, discovery mode (Table 1). Representative peptides for each biomarker candidate were selected based upon the robustness of their detection in CSF. For example, the quantitation of 41 peptides was compared in three AD CSF samples after one or two freeze thaws. The freeze thaw performance was of special importance for this experiment because of different collection protocols used for the AD CSF samples; some of the $\mathrm{AD}$ samples underwent one more freeze-thaw cycle than the other samples analyzed in this study. The 39 peptides selected in the final MRM panel include peptides from the 30 detectable proteins as well as peptides from blood contamination markers, a nonendogenous internal standard, and one CSF protein which was undetectable in the discovery experiment. The peptides are listed in Additional file 1: Table S1; they demonstrated no difference in peptide performance between 1 vs. 2 freeze-thaw cycles (Additional file 2: Figure S1, Pearson $r=$ 0.9938). Peptides with intra-assay and inter-assay CVs of less than $20 \%$ were analyzed in patient samples (a summary of peptide performance is shown in Additional file 1: Table S1. LODs, LOQs and \% CV was determined from the performance of 4 different calibration curves prepared on different days run in duplicate or triplicate). For the majority of proteins only one signature peptide was selected, with a few exceptions for lower abundance proteins or proteins for which specific peptides (i.e. isoform-specific) were previously published or known to have significance to disease (i.e. APOE4). When possible, species conserved peptides were selected (ex. cynomolgus monkey to human). Peptides were quantitated using the AQUA approach [27,28]; briefly, stable-isotope peptides for each candidate-peptide were synthesized and used as internal standards. The ratio of the light (endogenous) to heavy (stable-isotope-labeled) peptide was mapped to an external calibration curve of known ratios of pure light to heavy peptides. In addition, a nonendogenous protein (horse myoglobin) was spiked into CSF at the beginning of the sample preparation to serve as a quality control measure for sample processing [29].

\section{Diagnostic evaluation}

Thirty-nine peptides (Additional file 1: Table S1) were quantitated in baseline CSF tryptic-digests from 10 aged 
Table 1 Selected CSF AD biomarker candidates

\begin{tabular}{|c|c|c|c|c|}
\hline Uniprot ID & Identifier & Protein & Link to $A D$ & Change in AD \\
\hline P01009 & A1AT & a-1-antitrypsin & Neuroinflammation & {$[16-18,30-33]$} \\
\hline P04217 & $\mathrm{A} 1 \mathrm{BG}$ & a-1-beta-glycoprotein & Unknown & {$[17,20,34]$} \\
\hline P02768 & ALBU & Albumin & $A \beta$ polymerization & {$[17,18]$} \\
\hline P05067 & A4 & Amyloid precursor protein & $A \beta$ peptide precursor & {$[35]$} \\
\hline P51693 & APLP1 & Amyloid precursor-like protein 1 & Beta and gamma secretase substrate & [36] \\
\hline P02649 & APOE & Apolipoprotein E & Apolipoprotein, $A \beta$ clearance & {$[15,17,18,20,33,37]$} \\
\hline Q8TCZ8 & APOE4 & Apolipoprotein E4 & Apolipoprotein, risk factor for $A D$ & [22] \\
\hline P02749 & $\mathrm{APOH}$ & Apolipoprotein H (beta-2-glycoprotein 1) & Apolipoprotein & {$[15,20,21]$} \\
\hline P61769 & B2MG & Beta-2-microglobulin & A $\beta$-binding molecule & {$[15,17,19,20,22,37-41]$} \\
\hline P00450 & CERU & Ceruloplasmin & Antioxidant & {$[34,42,43]$} \\
\hline P36222 & CH3L1 & Chitinase-3-like protein 1 (YKL-40) & Neuroinflammation & {$[15,20,22,23,44]$} \\
\hline P10645 & CMGA & Chromogranin A & Neurodegeneration & {$[15,19,20,22,41,45-47]$} \\
\hline P10909 & CLUS & Clusterin (ApoJ) & Apolipoprotein, A $\beta$ clearance & {$[15-18,22,33,47]$} \\
\hline Q12860 & CNTN1 & Contactin 1 & Neurodegeneration & {$[16,18]$} \\
\hline Q02246 & CNTN2 & Contactin 2 & Neurodegeneration & {$[16,18]$} \\
\hline P01024 & $\mathrm{CO} 3$ & Complement component C3 & Neuroinflammation & {$[18,45,48,49]$} \\
\hline POCOL4 & $\mathrm{CO} 4$ & Complement component C4 & Neuroinflammation & {$[16,22,34,49]$} \\
\hline P01034 & CYTC & Cystatin C & A $\beta$-binding molecule & {$[15,19,20,22,32,38,41,47]$} \\
\hline O95502 & NPTXR & Neuronal pentraxin receptor & Neurodegeneration & {$[15,18,50]$} \\
\hline Q92823 & NRCAM & NrCAM & Neurodegeneration & {$[22,45,51]$} \\
\hline P00747 & PLMN & Plasminogen & A $\beta$ clearance & [18] \\
\hline P04156 & $\mathrm{PRIO}$ & Prion protein & $\beta$ Secretase BACE1 inhibitor & {$[39,40,52]$} \\
\hline P41222 & PTGDS & Prostaglandin-d2 synthase & $A \beta$ binding protein & {$[16,20]$} \\
\hline P02753 & RET4 & Retinol binding protein & Unknown & {$[15,17,18,37,39,40,53,54]$} \\
\hline P08294 & SODE & Superoxide dismutase & Target of oxidative damage in $A D$ & {$[15,34]$} \\
\hline P05452 & TETN & Tetranectin & Neurodegeneration & {$[15,16]$} \\
\hline P02787 & TFRE & (sero)transferrin & Oxidative damage in $A D$ & {$[15,17,34,39,40]$} \\
\hline P02766 & TTHY & Transthyretin & A $\beta$-binding molecule & {$[15,17,18,22,37,39,40,54-57]$} \\
\hline P62760 & VISL1 & Visinin-like protein 1 & Neurodegeneration & {$[25,26,58]$} \\
\hline P02774 & VTDB & Vitamin D Binding protein & A $\beta$-binding molecule & {$[15,18,39,40]$} \\
\hline
\end{tabular}

(>60 y), cognitively-normal control, $5 \mathrm{MCI}$, and $45 \mathrm{AD}$ subjects. The CSF sample demographics are summarized in Table 2. Mini-mental state exam (MMSE) cognitive scores were significantly different between control and $\mathrm{MCI}$ and control and $\mathrm{AD}$ subjects (t-test, $\mathrm{p}<0.001)$, and

Table 2 Demographics

\begin{tabular}{llll}
\hline Characteristics & $\begin{array}{l}\text { Cognitively } \\
\text { normal }\end{array}$ & $\begin{array}{l}\text { Mild cognitive } \\
\text { impairment }\end{array}$ & $\begin{array}{l}\text { Alzheimer's } \\
\text { disease }\end{array}$ \\
\hline $\mathrm{n}$ & 10 & 5 & 45 \\
$\mathrm{Sex}, \mathrm{M} / \mathrm{F}$ & $7 / 3$ & $2 / 3$ & $30 / 15$ \\
Age, median & 68.5 & 76 & 77.5 \\
Age, mean (range) & $68.8(64-75)$ & $74(66-80)$ & $76.9(61-90)$ \\
MMSE score, median & 30 & 24 & 20 \\
MMSE score, mean (range) & $29.4(25-30)$ & $23.4(21-26)$ & $19.7(6-27)$ \\
\hline
\end{tabular}

were consistent with the clinical diagnosis provided by the vendor (Table 2). Similarly, the trends observed for the classic CSF biomarkers $A \beta_{42}$, total tau, $p$-tau 181 were consistent with diagnosis (Figure 1A-C). There was a significant difference between the mean age of the groups (control vs. AD p $<0.005$, control vs. MCI $\mathrm{p}<0.05$ ), so it was important to include as a covariate in our analyses. Four peptides were significantly different between control and $\mathrm{AD}$ subjects (linear regression of log values adjusted for age and sex, $\mathrm{p}<0.05$, corrected by the Benjamini \& Hochberg method) (Table 3, Additional file 3: Figure S2). Only Chitinase-3-like protein 1 (CH3L1 aka YKL-40) was at or above the significance level of the common diagnostic biomarkers $\mathrm{A} \beta_{42}$, total tau, $\mathrm{p}-\operatorname{tau}_{181}$ and the MMSE cognitive scores. CH3L1 increased in AD by 1.6-fold (Figure 1D), which is similar to the degree of change observed for 

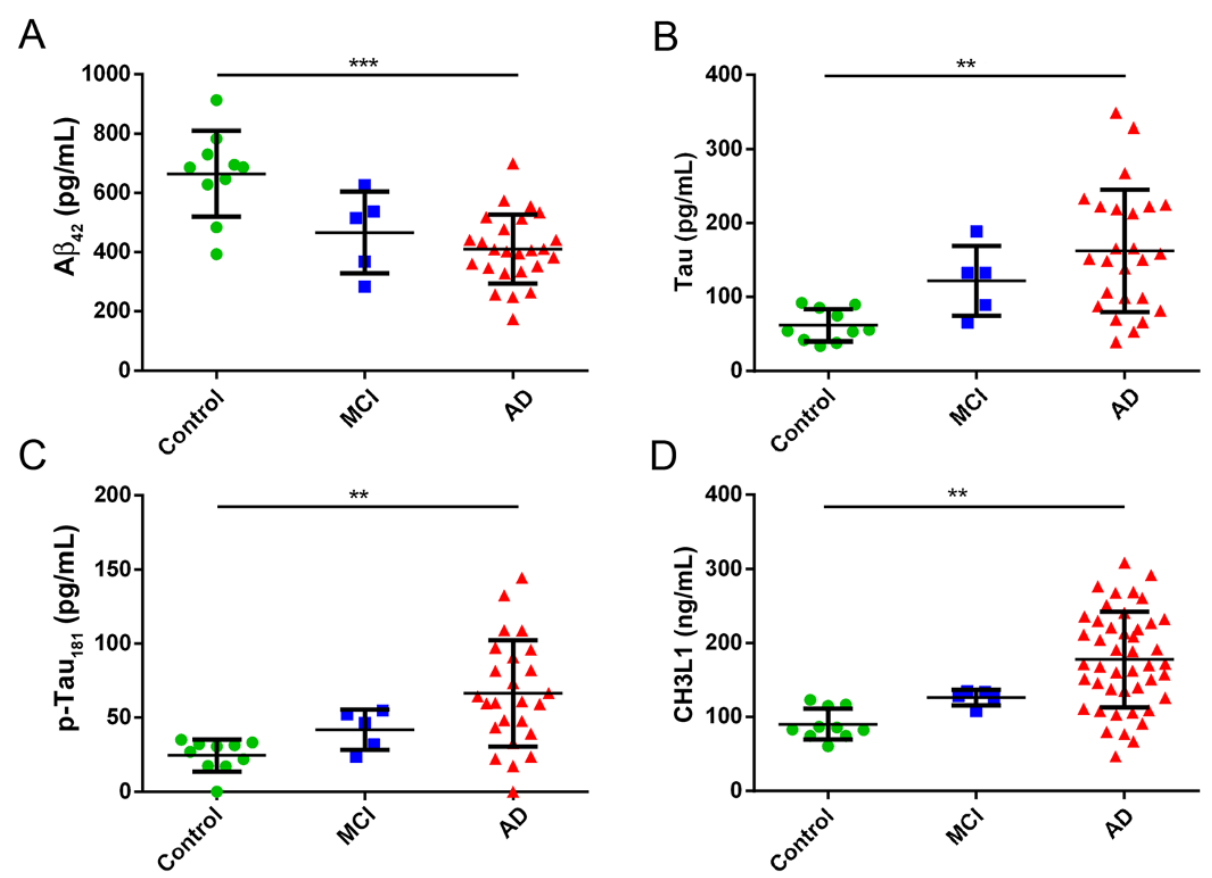

Figure 1 Difference in Chitinase-3-like protein 1 (CH3L1 aka YKL-40) is comparable with the change observed for $A \beta_{42}$, tau and p-tau 181 in $A D$ vs. aged cognitively-normal controls (age $>60 y$ ) (linear regression, ${ }^{* *} p=0.001-0.01,{ }^{* * *} p<0.001$ ). Control, green-circle, $M C l$ blue-square, AD red-triangle. $\mathbf{A}$. CH3L1, B. $A \beta_{42}$ C. total tau, $\mathbf{D}$. p-tau 181 .

$\mathrm{A} \beta_{42}$ and tau in these samples (Figure 1A-C). TTHY appears to change in MCI vs. control and 2 biomarkers, PTDGS and APOE_301 reached significance in AD vs. MCI (Table 3, Additional file 3: Figure S2), but due to the low subject number $(\mathrm{MCI}, \mathrm{n}=5)$, analysis of a greater number of subjects should be pursued to assess diagnostic potential.

\section{Longitudinal performance}

It is estimated that levels of $A \beta_{42}$ and tau change 1-2 decades prior to $\mathrm{AD}$ onset $[4,5]$. However, both markers demonstrate limited to no annual change in established AD patients [59-63]. One of the primary goals of our study was to evaluate the longitudinal stability of the candidate biomarkers. We estimated the annualized

Table 3 Summary of biomarkers that differ at baseline between diagnostic groups

\begin{tabular}{|c|c|c|c|c|c|c|}
\hline \multirow[b]{3}{*}{ Biomarker } & \multicolumn{6}{|c|}{ Group comparison } \\
\hline & \multicolumn{2}{|c|}{$\mathrm{AD} / \mathrm{Ctl}$} & \multicolumn{2}{|c|}{$\mathrm{MCl} / \mathrm{Ctl}$} & \multicolumn{2}{|c|}{$\mathrm{AD} / \mathrm{MCl}$} \\
\hline & p-value & Fold difference & p-value & Fold difference & p-value & Fold difference \\
\hline MMSE & $<0.001$ & 0.63 & & & & \\
\hline$A \beta 42$ & $<0.001$ & 0.60 & & & & \\
\hline CH3L1_290 & 0.003 & 1.6 & & & & \\
\hline Total Tau & 0.004 & 2.0 & & & & \\
\hline TTHY_56 & 0.006 & 1.2 & 0.04 & 1.2 & & \\
\hline$p$-tau181 & 0.007 & 2.1 & & & & \\
\hline A4_117 & 0.031 & 0.7 & & & & \\
\hline CO3_1172 & 0.031 & 1.4 & & & & \\
\hline PTGDS_23 & & & & & 0.034 & 0.82 \\
\hline APOE_301 & & & & & 0.049 & 0.73 \\
\hline
\end{tabular}

$\mathrm{p}$ values represent linear regression comparison of log values (corrected by the Benjamini \& Hochberg method), adjusting for age and sex, and the table includes all measurements with $p<0.05$. Fold difference reflects ratio of the average baseline measurements between groups. Differences for MMSE and ELISA measurements of $A \beta 42$, total tau and $p$-tau are included for reference (italicized). ( $A D n=45, C t I n=10, M C I n=5, a g e d>60 y$ ). 
rates of change via a linear mixed-effects model using three time points collected repeatedly from the same patients (baseline, 3-8 mo., 11-16 mo.) including age and sex as covariates [64]. As expected, both $A \beta_{42}$ and tau remained stable in the $\mathrm{AD}$ subjects' samples analyzed in this study (Figure 2) (\% annual change for $\mathrm{A} \beta_{42}=-0.1 \%$, $95 \% \mathrm{CI}=-7.3-7.7 \%$ annual change for tau $=-5.4,95 \%$ $\mathrm{CI}=-16.1-6.6)$. P-tau trended toward a decrease in $\mathrm{AD}$, but the change from baseline did not reach significance (\% annual change for $\mathrm{p}$-tau $=-10.8 \%, 95 \% \mathrm{CI}=-21.4-1.3$ ). The annual rate of yearly change was estimated for all peptides in $\mathrm{AD}$ subjects (Figure 3). The majority of peptides were stable over time, however, four peptides demonstrated significant decreases over time in AD as indicated by the $95 \%$ confidence interval error bars ( 10\% per year) (amyloid precursor protein, A4_117; neuronal pentraxin receptor, NPTXR; Chromogranin A, CMGA; and NrCAM) (Figure 3). The individual trajectories and the mean group slope are shown in Figure 4 for the four potential longitudinal biomarkers. There was no significant change from baseline observed in a smaller set of aged control and MCI patients (Figure 4).

\section{Correlation analysis}

The relationship of all peptides with each other as well as with $\mathrm{A} \beta_{42}$, tau and $\mathrm{p}-\mathrm{tau}_{181}$ was compared. Spearman rank correlations were assessed in all samples, and the most significant correlations $(|\mathrm{r}>0.8|)$ are shown in Table 4. Chromogranin A (CMGA), NrCAM and Neuronal pentraxin receptor (NPTXR) were the most highly correlated biomarkers (Figure 5) with correlation coefficients greater than 0.9 for all subjects independent of group, sex, age or time point. When measured by ELISA, CMGA and NrCAM were also highly correlated, and the rank order was consistent with the MRM result (Figure 5D, $\mathrm{R}=0.93$ ); thus confirming the observed correlation by an independent method. In addition, within $\mathrm{AD}$ patients (baseline) these three tightly correlated peptides did not correlate with levels of CSF total protein $(n=32)$ or $A \beta_{42}$ $(\mathrm{n}=21)$ (Additional file 1: Table S2), however they did correlate with tau $(\mathrm{n}=21)$ (CMGA $\mathrm{R}=0.69$, NPTXR $\mathrm{R}=0.71$, NrCAM $\mathrm{R}=0.74$ ) (Additional file 1: Table S2).

\section{Discussion}

Using a multiplexed, targeted-proteomics approach we evaluated candidate biomarkers for $\mathrm{AD}$ that were previously reported in discovery proteomic experiments to change with disease. At least one surrogate peptide was selected for each protein, and 4 specific transitions were selected for each peptide. Stable-isotope labeled peptides (heavy) were used as internal standards for every endogenous peptide (light), and the ratio of the peptide pair (light to heavy) was used for absolute quantitation. Using CH3L1 as an example (Figure 1D), absolute quantitation by this approach yields results similar to that of traditional immunoassays [22,23,44,65].

One of the major benefits of our approach, especially when working in a less-complex matrix like CSF, is that sample preparation does not require sample enrichment approaches. For example, sample enrichment using antibodies, even in the case of depleting the most abundant proteins, such as albumin, can add bias due to co-depletion of proteins of interest [66]. However, enrichment strategies are usually needed when additional sensitivity is required. In this assay, the concentration range in CSF for the 28 proteins detected was $28 \mathrm{ng} / \mathrm{mL}$ to $13.8 \mu \mathrm{g} / \mathrm{mL}$, which is consistent with the expected dynamic range of current instruments. Visinin like protein 1 (VILIP-1) was below the level of detection for all three peptides that were monitored; targeted-enrichment strategies or development of a sensitive immunoassay will be required to evaluate this candidate biomarker.

While not a primary focus of our study due to our small group sizes, we did evaluate the diagnostic performance of all the candidate biomarkers in comparison with the classic AD CSF biomarkers. The directionality and fold-difference observed between diagnostic groups was as expected for $\mathrm{A} \beta_{42}$, tau and p-tau in our sample set (Figure 1, Table 3); this result gave us confidence that these samples are representative of their respective diagnostic groups and that they could be used to evaluate the performance of the candidate biomarkers. After correction for multiple comparisons testing, a number of peptides reached significance in differentiating the diagnostic groups (Table 3). However, due to the small group size, replication with more individuals needs to be performed, especially for the MCI group comparisons. The observed modest differences between groups (0.6-2 fold-differences) are comparable with what others have reported; proteomic studies of larger sample sets have demonstrated that the majority of candidates change by less than 2 -fold in $\mathrm{AD}$ $[16,22]$. Extending from sporadic AD to familial AD, Ringman et al. also reported that complement component C3 (CO3) increased in disease by 1.3 [34], in comparison with our observed changes of 1.4. Also consistent with previous reports, the traditionally used biomarkers $A \beta_{42}$, tau and $\mathrm{p}-\mathrm{tau}_{181}$ were the most significant and specific markers differentiating AD patients from control. The other significant biomarkers detected lack specificity; they have also been reported to change in other neurodegenerative diseases including Parkinson's disease and multiple sclerosis $[15,16,67]$. The biomarkers evaluated in this study may have greater utility for disease-staging rather than diagnostics [22] or for monitoring therapeutic response, especially if used in combination; if multiple molecules from the same pathway change in response to treatment, it would give one higher confidence of a therapeutic effect. 

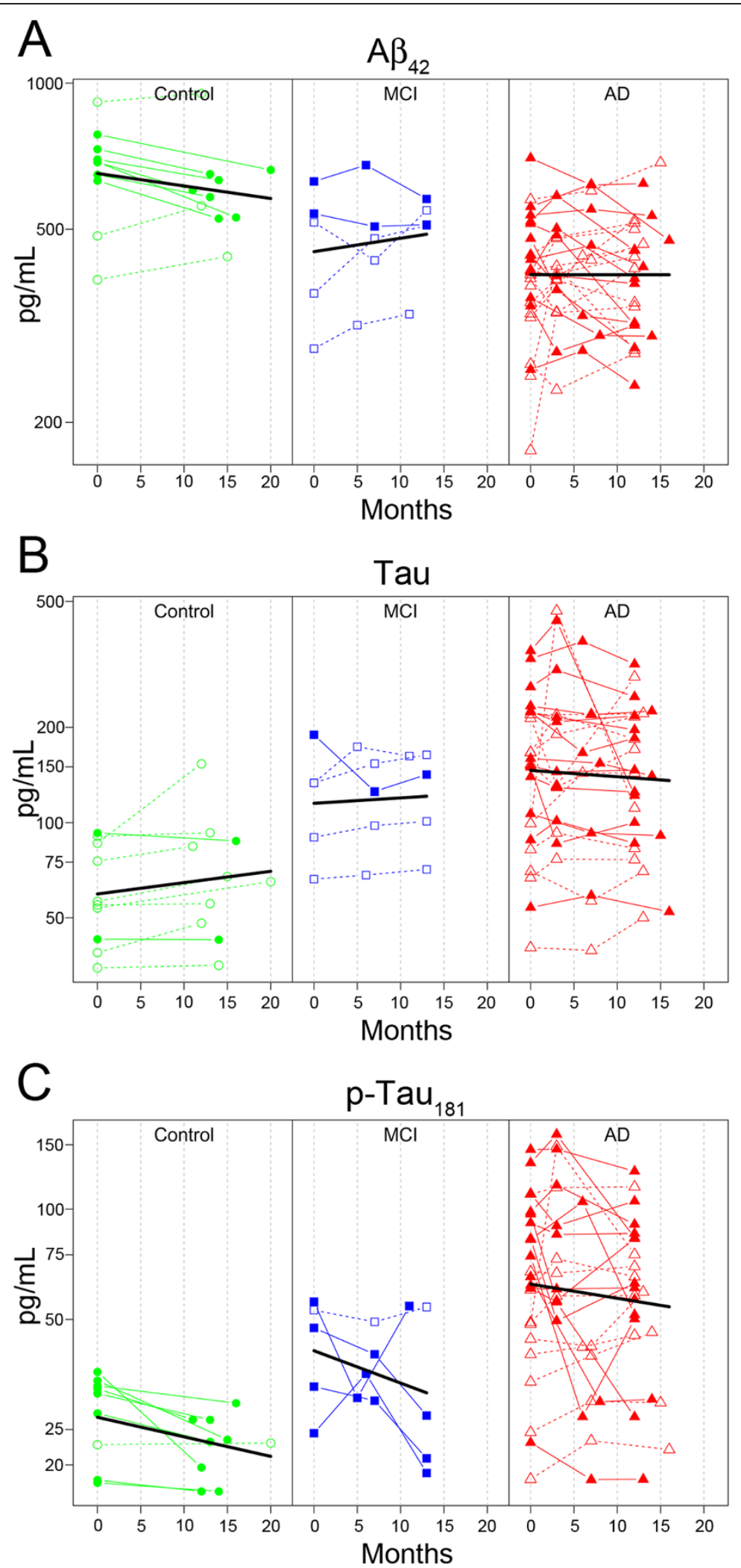

Figure 2 Classical CSF biomarkers of $A D$ are stable in established disease. Black-line mean slope. Control, green-circle, $M C l$ blue-square, $A D$ red-triangle. Closed symbols, decliners. A. A $\beta_{42}$, B. total tau, C. p-tau 181 . 


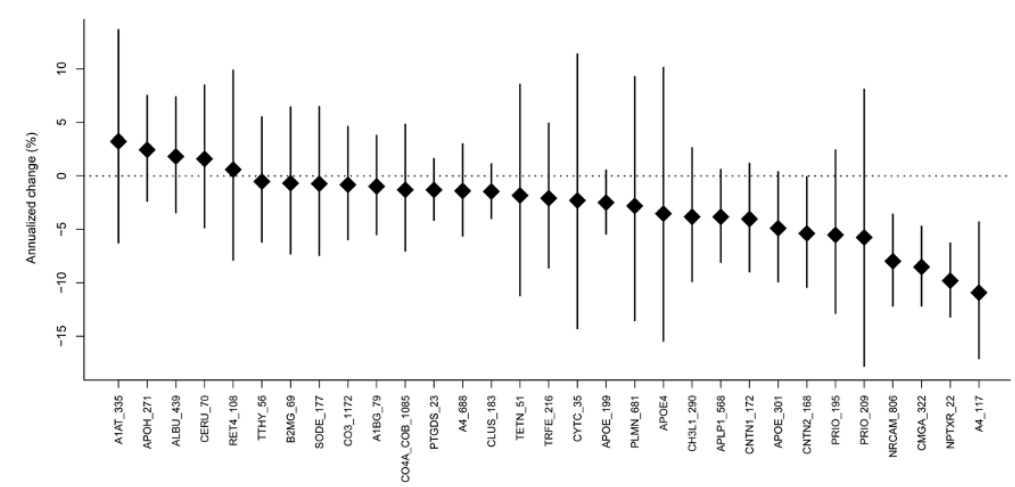

Figure 3 Estimated annual change of biomarkers in AD patients $(n=45)$ adjusted for age and sex. Dot, mean change. Line, 95\% confidence interval.

It is important to characterize the longitudinal stability of a candidate biomarker prior to use in the clinic. Multiple studies have demonstrated that CSF A $\beta_{42}$ levels stabilize and plateau in established AD [59-63]. Similarly CSF tau and p-tau appear to demonstrate longitudinal stability [68], though some studies have noted a slight continued longitudinal increase in tau $[60,63]$. In our longitudinal assessment of the classic AD biomarkers, $A \beta_{42}$ and tau levels were stable over the course of a year in our AD patients (Figure 2), consistent with previous reports. Similar to $A \beta_{42}$ and tau, the majority of peptides were stable over time (11-16 months) in AD patients (Figure 3). There were four peptides (A4_117, CMGA_322, NPTXR_22, and
NRCAM_806) that declined significantly by approximately $10 \%$ per year in the $\mathrm{AD}$ patients but not in aged control or MCI patients (Figure 4). P-tau trended toward decline over time in 14 of 24 patients (Figure 2). A decline in p-tau ( $2 \mathrm{pg} / \mathrm{mL} /$ year) has been observed previously in sporadic $\mathrm{AD}$ patients [69], and more recently in autosomaldominant $\mathrm{AD}$ patients [70]. Fagan et al. also showed that levels of VILIP-1 decreased after the onset of disease [70], suggesting that at later stages of disease a decline in CSF biomarkers, like VILIP-1, are reflective of neuronal loss. The four markers identified in this study are also neuronal markers, and are potential progression markers in Alzheimer's patients that will be further evaluated in additional longitudinal sample sets.
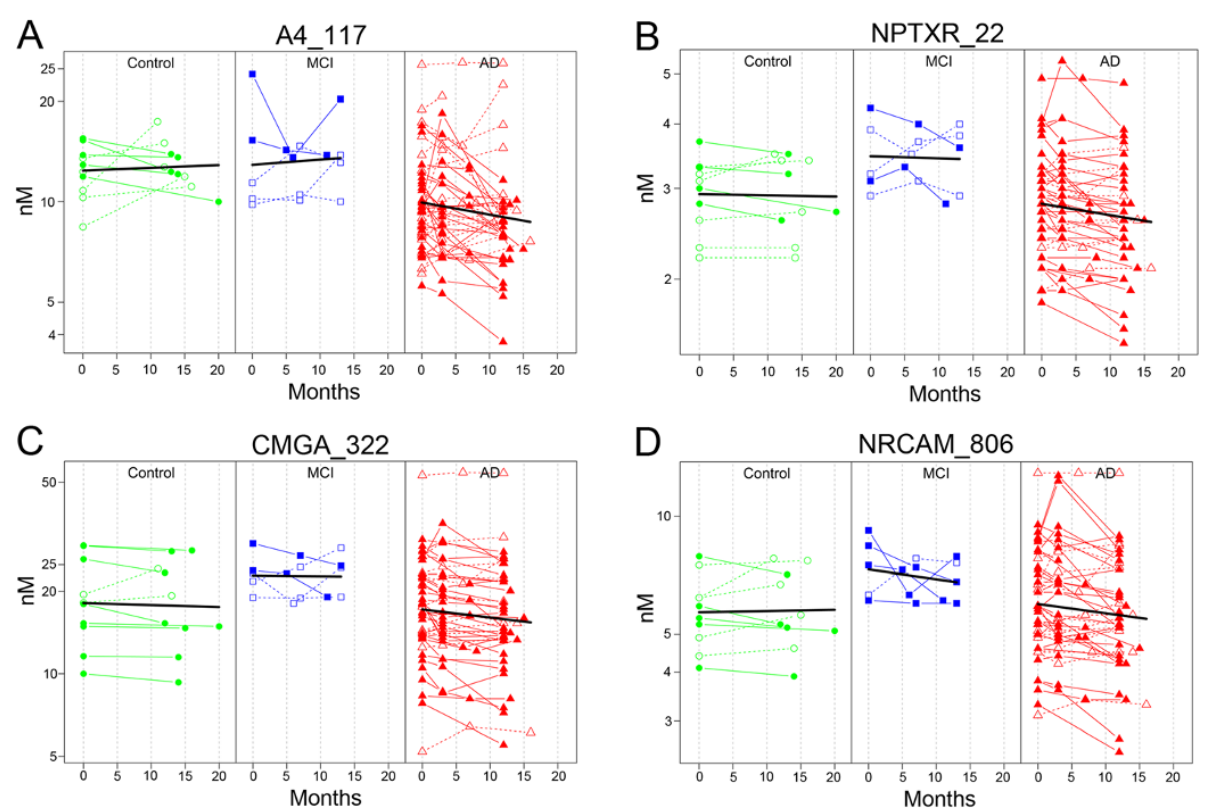

Figure 4 Potential longitudinal biomarkers in established AD patients. Black-line mean slope. Control, green-circle, $M C l$ blue-square, $A D$ red-triangle. Closed symbols, decliners. A. Amyloid precursor protein peptide (A4_117), B. Neuronal pentraxin receptor (NPTXR), C. Chromogranin A (CMGA), D. NrCAM. 
Table 4 Most significant correlations for all time points and all groups (Spearman) $(R>0.8)$

\begin{tabular}{lc}
\hline Peptide $\mathbf{X}$ vs. Peptide $\mathbf{Y}$ & R (Spearman rank) \\
\hline CMGA_322 vs. NRCAM_806 & 0.93 \\
CMGA_322 vs. NPTXR_22 & 0.93 \\
NPTXR_22 vs. NRCAM_806 & 0.92 \\
APOE_301 vs. B2MG_69 & 0.88 \\
CYTC_36 vs. TETN_51 & 0.88 \\
B2MG_69 vs. TETN_51 & 0.88 \\
A4_688 vs. NRCAM_806 & 0.87 \\
B2MG_69 vs. PRIO_195 & 0.87 \\
CLUS_183 vs. PTDGS_23 & 0.87 \\
A4_688 vs. CMGA_322 & 0.87 \\
A4_688 vs. NPTXR_22 & 0.85 \\
PRIO_195 vs. TETN_51 & 0.83 \\
APOE_301 vs. PRIO_195 & 0.83 \\
CERU_70 vs. CO3_1172 & 0.82 \\
CERU_70 vs. PLMN_681 & 0.81 \\
APOE_199 vs. APOE_301 & 0.80 \\
\hline
\end{tabular}

Interestingly, the potential progression markers CMGA, NrCAM and NPTXR were also highly correlated (Figure 5). The fourth candidate progression marker amyloid precursor protein (APP) peptide A4_117 was also correlated with the three other peptides, however, the Spearman rank correlation coefficient was below our $|\mathrm{R}>0.8|$ cut-off (A4_117 correlations: NrCAM R $=0.65$, CMGA $\mathrm{R}=0.62$, NPTXR $\mathrm{R}=0.6$ ). Another APP peptide quantitated in this study, A4_688, did not demonstrate significant longitudinal change. The lack of strong correlation between the two APP peptides, A4_117 and A4_688 (Spearman rank $R=0.42$ ), may be a consequence of differential CSF kinetics of APP cleavage fragments (Figure 6). Based on the full-length sequence of APP A4770, A4_117 corresponds to amino acids (a.a.) 117-132, which is present in soluble APP (sAPP) $\alpha$ (a.a.18-687) and sAPP $\beta$ (a.a.18-671) as well as N-APP (a.a.18-286). In contrast, A4_688 corresponds to a.a. 688-699 from full-length APP as well as a.a. 17-28 within $A \beta$ [71]. The differential behavior of these peptides demonstrates the importance of distinguishing peptidelevel quantitation from total protein quantitation, and caution against algorithms that automatically combine peptide quantitation into a single protein quantitation.

The correlations were remarkably high for some of these biomarkers and possible analytical factors were

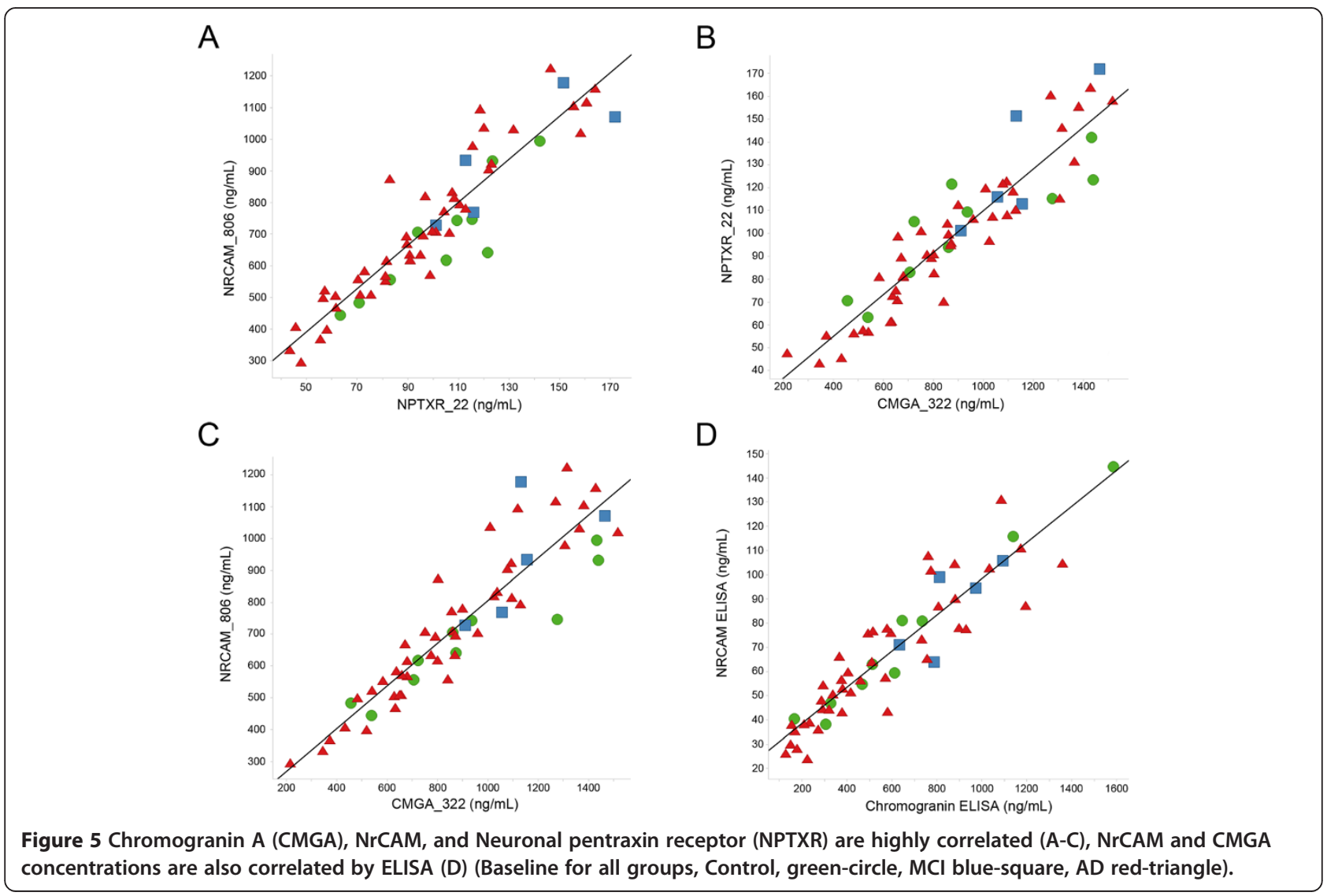



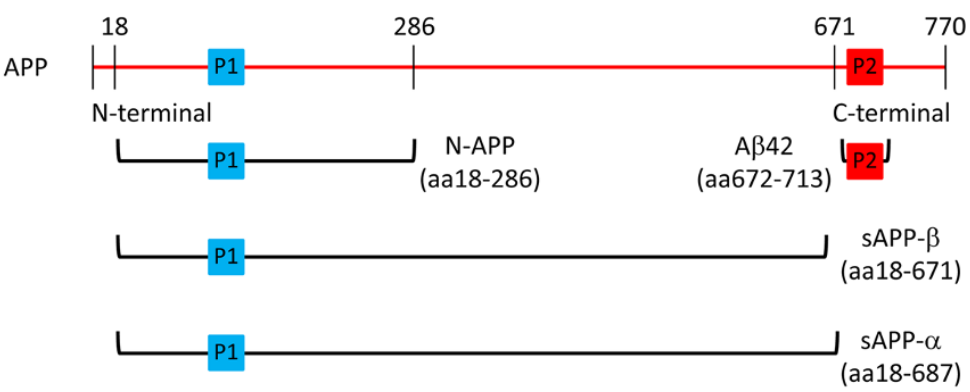

P1 peptide 1: aa117-132 [CLVGEFVSDALLVPDK]

P2 peptide 2: aa688-699 [LVFFAEDVGSNK]

Figure 6 Peptides from different regions of Amyloid Precursor Protein (APP, A4) reflect different processing products.

evaluated. The majority of potential analytical artifacts were ruled out; for example, peptide properties including retention time and $m / z$ were different in each case. To support the hypothesis that the correlations are not an artifact of the detection method, NrCAM and CMGA levels were analyzed using ELISAs. A similar rank order was observed in the MS assay and ELISA (Figure 5D). Interestingly, the absolute levels measured by the $\mathrm{NrCAM}$ ELISA were significantly lower than that measured by the MS assay. The difference in absolute value between the NrCAM ELISA and MS result may be due to the fact that NrCAM exists as multiple isoforms in CSF. The antibody used in the ELISA may not detect all the isoforms; however, the peptide used for the MS assay is present in all $5 \mathrm{NrCAM}$ isoforms, which would account for the higher value observed by MS. Although the absolute values were different from the two methods used, the fact that the rank orders are maintained support the hypothesis that the high correlation for some biomarkers reflects a common biological process. CMGA, NPTXR, NrCAM, and A4_117 and A4_688 are all produced in neurons, and changes in these peptides may be reflective of neurodegeneration. $\mathrm{NrCAM}$ is an adhesion molecule present on synapses [45,72]. CMGA is a prohormone that is packaged in dense-core synaptic vesicles [46,73,74]. NPTXR and APP are both integral-membrane proteins. NPTXR has been implicated in synaptic plasticity $[75,76]$, and APP is known to be critical to synapse formation and function [77]. Given the diverse biological roles of these proteins, the observed correlations suggest that coordinated changes in CSF may reflect pathologies beyond $\mathrm{A} \beta$ and tau (e.g. synaptic function or secretion mechanisms). Interestingly, CMGA, NPTXR, and NrCAM are also positively correlated with tau within our AD samples $(R=0.69,0.71,0.74$, respectively, Additional file 1: Table S2), although not as strongly as they are correlated with each other. VILIP-1, a potential marker of neurodegeneration, is also positively correlated with tau [26]. Future studies are needed to increase our understanding of the underlying cause of these correlations, the spectrum of other CSF proteins that are correlated with this initial cluster, and the longitudinal performance and utility of the correlations.

\section{Conclusions}

It is now clear that Alzheimer's disease pathology begins years before the onset of clinical symptoms, and therapeutic trials are beginning to focus on treating patients prior to the onset of dementia. Thus, the need for biomarkers that can increase the accuracy of early diagnosis and reflect the success of treatment is critical for AD researchers, clinicians, and patients. Ideally, biomarkers will be discovered that reflect multiple processes such as neuroinflammation, neuronal stress and neuronal dysfunction, which will enable intervention prior to significant neuronal loss. In addition, biomarkers are needed to monitor progression of disease in established patients. To accelerate the assessment of candidate biomarkers, we developed an absolute quantitative assay for 30 candidate protein biomarkers (Table 1). Biomarkers that were significantly different between diagnostic groups at baseline (fold differences ranging from 0.6-1.6) (Table 3), reproduced published discovery proteomic results. Four of the markers emerged as potential progression markers in AD (Figure 4). Multiplexing enabled the exploration of relationships between CSF biomarkers; we discovered highly correlated proteins that may serve as markers of neurodegeneration in established AD patients (Figure 5). Multiplexed, targeted-proteomics proved to be a robust approach with relatively rapid assay development time enabling the assessment and prioritization of biomarker discovery candidates. This approach promises to fill a much needed gap in clinical biomarker development. 


\section{Methods}

\section{Source of CSF}

CSF was purchased from Bioreclamation, LLC (Hicksville, NY) (pooled cynomolgus monkey and pooled human CSF used in discovery experiments), Folio Biosciences (Columbus, $\mathrm{OH}$ ) (individual longitudinal AD only) and PrecisionMed, Inc. (San Diego, CA) (individual longitudinal Control, $\mathrm{MCI}$ and $\mathrm{AD}$ ). Details on sample collection were provided by the vendors. All donors provided informed consent for use of these studies with institutional review board approval for human collection protocols. CSF was collected in the morning under fasting condition. Lumbar punctures were performed at L3-L4 or L4-5 using a sprotte needle (5 mL), and the CSF was centrifuged and then immediately aliquoted in polypropylene tubes and snap frozen at $-80^{\circ} \mathrm{C}$. Bloody taps or visually "pink" CSF were excluded. AD or MCI subjects had MMSE between 14 and 28, were greater than 60 years old, Hachinski score $\leq 4$, diagnosed with dementia or MCI established by a clinical examination and documented by MMSE and other neuropsychological tests. Aged cognitively-normal individuals were 64-75 years old, healthy, exhibited normal memory function documented by results within the normal range for CDR word recognition test, and had an MMSE score of greater than 28. The diseased population samples from PrecisionMed were thawed at the vendor for aliquoting, and thus underwent one more freeze-thaw cycle than the other samples analyzed in this study.

\section{Total protein measurements}

Concentrations of CSF total protein were provided by Folio Biosciences as part of the clinical data for each $\mathrm{AD}$ subject.

\section{Immunoassay measurements of CSF $A \beta_{1-42}$, Tau, and $\mathrm{p}-\mathrm{Tau}_{181}$}

INNO-BIA AlzBio3 Kit (Innogenetics, RUO) was used according to the manufacturer's protocol. Briefly, beads conjugated to monoclonal antibodies against $\mathrm{A} \beta_{1-42}$ (4D7A3), Tau (AT120), or p-Tau 181 (AT270) were mixed with biotinylated monoclonal antibodies against the same targets (3D6 for A $\beta 1-42$, HT7 for Tau and p-Tau ${ }_{181}$ ). $75 \mu \mathrm{L}$ of undiluted CSF was incubated overnight at room temperature with mild agitation. The beads were then washed, and a solution of streptavidin-PE was added to the beads for $1 \mathrm{~h}$ to enable detection of bound analytes. After an additional wash, a read solution was added to the beads and they were then analyzed with the Bioplex 200 system (Biorad, Hercules, CA). Only a subset of the AD samples (25 of 45), representative of both vendors, were assayed due to a limited availability of CSF for some subjects.

\section{CSF tryptic digestion and peptide quantitation}

$400 \mu \mathrm{L}$ of CSF was spiked with $100 \mathrm{ng}$ of equine myoglobin (Sigma, St. Louis, MO) and concentrated to $30 \mu \mathrm{L}$ in a $3 \mathrm{kDa}$ Amicon centrifugal concentrator (Millipore, Billerica, MA). Samples were denatured in $40 \%$ trifluoroethanol (TFE) (Sigma) prepared in $100 \mathrm{mM}$ triethylammonium bicarbonate (TEABC) (Sigma) $\left(1 \mathrm{~h} 37^{\circ} \mathrm{C}\right)$. Samples were reduced with $5 \mathrm{mM}$ dithiothreitol (DTT) (30 min RT), alkylated with $20 \mathrm{mM}$ iodoacetamide (IAM) (30 min, RT in the dark), and quenched with an additional $5 \mathrm{mM}$ DTT (15 min, RT). Samples were diluted to 10\% TFE with $100 \mathrm{mM}$ TEABC, and then digested with trypsin (1:25, $18 \mathrm{~h}, 37^{\circ} \mathrm{C}$ ). The digestion was stopped by the addition of formic acid. The final volume of all digests was measured. An aliquot of the total digest $(48 \mathrm{uL})$ was spiked with a mixture of stable-isotope-labeled AQUA peptides $(2 \mathrm{uL})$ (Cell Signaling Technologies, Danvers, MA) prior to LC-MS/MS analysis. Protein-AQUA ${ }^{\text {su }}$ peptides were synthesized by Cell Signaling Technologies and purified by reversed-phase HPLC, and analyzed by MALDI-TOF MS and nanospray tandem MS. An accurate peptide concentration was measured by amino acid analysis, and provide by the vendor. Heavy AQUA peptides to be spiked into samples were diluted and pooled before use to concentrations that were within 10-fold of endogenous protein levels and ranged from $2-100 \mathrm{fmol} / \mathrm{uL}$ depending on analyte. In addition, a pool of heavy (stable-isotope labeled) and light (unlabeled) AQUA peptides was prepared and diluted serially to generate calibration curves. The heavy peptide mixture was prepared first. The light peptide was diluted serially using the heavy peptide mixture to hold the concentration of the heavy peptide constant (at the same concentration used for the internal standard spike). Heavy and light peptides used for calibration curves were prepared and qualified in an artificial CSF matrix (bovine serum albumin digest) to select 4 transitions for MRM, establish limits of detection (LOD) and limits of quantitation (LOQ). The observed fmol on-column (2 uL of digest) was converted to $\mathrm{nM}$ using a volume correction factor to express the result in relation to the original sample volume. The ranges in human CSF samples and biologic functional roles are summarized in Additional file 1: Table S1 for peptides that demonstrated consistent performance $(<20 \% \mathrm{CV})$. Values represent the median of 4 different calibration curves prepared on different days run in duplicate or triplicate.

\section{Discovery LC-MS/MS analysis}

Digested proteins from pooled CSF (cynomolgus monkey, human young normal and Alzheimer's disease subjects) were analyzed by capillary reverse phase liquid chromatography-electrospray ionization tandem mass spectrometry. Aliquots ( $5 \mu \mathrm{L}$ of 25 total) were loaded onto the trapping column $(\mathrm{BEH} \mathrm{C18;180 \mu M}$ i.d. $\times 20 \mathrm{~mm}$ with 
$5 \mu \mathrm{m}$ particles) of a nanoAcquity (Waters, Milford, MA) ultra high pressure liquid chromatography system and eluted through a resolving column (BEH C18; $100 \mu \mathrm{m}$ i.d. $\times 100 \mathrm{~mm}, 1.7 \mu \mathrm{m}$ particles) at a flow rate of $1 \mu \mathrm{L}$ per minute using a linear gradient from 2 to $30 \%$ solvent B over 35 minutes followed by a ramp to $50 \% \mathrm{~B}$ in 3 minutes and a step and hold at $90 \%$ B for 5 minutes, returning to $2 \%$ B for a 7 minute re-equilibration. Solvent A was $0.1 \%$ formic acid in water and solvent $\mathrm{B}$ was $0.1 \%$ formic acid in acetonitrile. Eluted peptides were directed to the electrospray source (CaptiveSpray; Michrom Bioresources, Inc., Auburn, CA) of an LTQ-orbitrap mass spectrometer (Thermo Scientific, Waltham, MA) operated in a "top-8" data-dependent mode whereby high resolution scans of peptide masses in the orbitrap analyzer were followed by ion trap collisioninduced dissociation of the 8 most abundant multiply charged ions. Tandem mass spectra were searched against the "UniProt" database of human proteins using the Mascot program (Matrix Science Ltd.) using a "semi-tryptic" enzyme specificity and $25 \mathrm{ppm}$ precursor ion tolerance, with cysteine carbamidomethylation as a static modification and allowing for oxidized methionine as a variable modification. Database hits were filtered to a false discovery rate of less than one percent using a "target-decoy" linear discriminant procedure.

\section{Targeted LC-MRM analysis}

Samples $(2 \mu \mathrm{L})$ were loaded onto a nanoAcquity UPLC (Waters, Milford, MA), desalted on a Symmetry ${ }^{\circ}$ C18 trap column $(180 \mu \mathrm{m} \times 20 \mathrm{~mm}, 5 \mu \mathrm{m})$ (Waters) and separated on a BEH130 C18 $(100 \mu \mathrm{m} \times 100 \mathrm{~mm}, 1.7 \mu \mathrm{m})$ (Waters) at a flow rate of $1 \mu \mathrm{L} / \mathrm{min}$ over a $60 \mathrm{~min}$. gradient $(2 \%$ acetonitrile (ACN) $0.1 \%$ formic acid (FA) to $30 \% \mathrm{ACN}$, $0.1 \%$ FA over 40 min; 30-98\% ACN, 0.1\% FA over 10 min; $98 \% \mathrm{ACN}, 0.1 \% \mathrm{FA}$ for $5 \mathrm{~min}$; reequilibrate $2 \% \mathrm{ACN}$, $0.1 \%$ FA). Peptides were detected by a QTRAP $^{\circledR} 5500$ (AB SCIEX, Framingham, MA) equipped with an Advance Captivespray ${ }^{\text {mim }}$ source (Michrom Bioresources, Inc. Auburn, CA). Scheduled MRM methods were prepared using Skyline v1.3 [78] and imported into Analyst 1.5.2 (ABSCIEX). The QTRAP 5500 was operated in positive ion mode using scheduled MRM. Result files were processed and quantitated using Multiquant ${ }^{\mathrm{mix}} \mathrm{v} 2.1$ with Scheduled MRM ${ }^{\mathrm{m}}$ algorithm (AB SCIEX), and the results exported for further statistical analysis. Calibration curves were generated using a mixture of light and heavy AQUA peptides spiked into artificial CSF $(10 \mu \mathrm{g} / \mathrm{mL}$ bovine albumin digest prepared in the same manner as CSF samples).

\section{NrCAM and Chromogranin A enzyme-linked immunosorbent assays (ELISAs)}

CSF samples were analyzed using commercially available ELISAs for NrCAM (R\&D Systems, Inc., Minneapolis,
MN) and Chromogranin A (ALPCO Diagnostics, Salem, $\mathrm{NH}$ ). The assays were performed according to the manufacturers' instructions. CSF samples were assayed in duplicate and had undergone one previous freeze-thaw cycle after receipt from vendor. For the NrCAM ELISA, CSF samples were diluted $1 / 64$ in Reagent Diluent (Catalog \# DY995 R\&D Systems) and $100 \mu \mathrm{L}$ of the diluted samples and kit standards were added per well. Absorbance was measured at $450 \mathrm{~nm}$ with wavelength correction at $570 \mathrm{~nm}$ on a VersaMax plate reader (Molecular Devices, Sunnyvale, CA). For the Chromogranin A ELISA, CSF samples were diluted $1 / 4$ in CgA Assay Buffer (ALPCO Diagnostics) and $25 \mu \mathrm{L}$ of the diluted samples and kit standards and controls were added per well. Absorbance was measured at $450 \mathrm{~nm}$ with wavelength correction at $595 \mathrm{~nm}$ on a VersaMax plate reader.

\section{Statistical analysis}

Results were imported into $\mathrm{TIBCO}^{\circ}$ Spotfire $^{\circ}$ 4.0.2 (TIBCO ${ }^{\circ}$ Software Inc, Somerville, MA) and R statistical computing and graphics software. Analyses included data QC for peptide performance (coefficient of variance), $\mathrm{QC}$ of sample preparation (equine myoglobin), group comparisons (linear regression, (p-values corrected by the Benjamini \& Hochberg method)), longitudinal analysis, and correlation analysis (Pearson and Spearman). Measured "values" were transformed using a log base 10 transformation. Annualized rates of change of "values" were estimated via a linear mixed-effects model [64] implemented with the 'nlme' package in $\mathrm{R}$ [79] using "patients" as random effect. In both the baseline group comparison model and the longitudinal analysis for annualized rate of change, we adjusted for age as a continuous covariate, sex, and interactions between age and sex.

\section{Additional files}

\begin{abstract}
Additional file 1: Table S1. Selected peptides for CSF AD biomarke candidates, peptide performance and biological protein function. Table S2. CSF total protein and $A \beta_{42}$ do not correlate with chromogranin (CMGA), neuronal pentraxin receptor (NPTXR) or NrCAM, but tau and p-tau ${ }_{181}$ do (Spearman rank correlations in AD patients at baseline).
\end{abstract}

Additional file 2: Figure S1. The majority of peptides are stable after one or two freeze-thaw cycles. Log of the mean ratio (light to heavy peptide pair) observed for 42 peptides between 1 or two freeze thaw cycles in CSF from three AD patients (shape and color by patient).

Additional file 3: Figure S2. Comparison of levels of detectable peptide biomarkers with inter-assay CVs of $<20 \%$ in aged ( $>60 y$ ) cognitively-normal controls $(n=10), M C l(n=5)$, and AD $(n=45)$ individuals. Differences between control and $A D$ that reached significance are indicated with an asterisk ${ }^{*} p=0.01-0.05,{ }^{* *} p=0.001-0.01,{ }^{* * *} p<0.001$, linear regression comparison of log values corrected by the Benjamini \& Hochberg method) (Control, green-circle, MCl blue-square, AD red-triangle).

\section{Abbreviations}

AD: Alzheimer's disease; CSF: Cerebrospinal fluid; MCl: Mildly-cognitively impaired; MRM: Multiple-reaction monitoring; $A \beta$ : Amyloid beta; p-tau: Phosphorylated tau; LC: Liquid chromatography; MS: Mass 
spectrometry; ApoE: Apolipoprotein E; MMSE: Mini-mental state exam; CH3L1: Chitinase-3-like protein 1; B2MG: Beta-2-microglobulin; APP: Amyloid precursor protein (A4); NPTXR: Neuronal pentraxin receptor; CMGA: Chromogranin A; CERU: Ceruloplasmin; CO3: Complement component C3.

\section{Competing interests}

All authors are employees of Genentech, Inc. a member of the Roche group, and receive a fixed salary.

\section{Authors' contributions}

KRW, WRM, LH conceived and designed the experiments. DA performed discovery proteomics LC/MS experiments. KRW developed the LC/MS MRM assay and processed and analyzed CSF samples. SPS and AMS analyzed CSF samples using different ELISAs. JH assisted with data analysis. YZ performed the statistical analysis of all data. KRW, WRM, SK, and LH wrote the paper. All authors edited and revised the manuscript, and gave final approval of the version to be published.

\section{Acknowledgements}

Thanks to Mausumi Debnath, Harbeen Grewal and colleagues at Anshin Biosolutions for their assistance in the formatting and editing of the manuscript. Also, thanks to Sock-Cheng Lewin-Koh and Qinghua Song from the nonclinical biostatistics department at Genentech for their statistical advice.

\section{Author details}

'Department of Phamacodynamic Biomarkers within Development Sciences, Genentech, Inc. (a member of the Roche Group), 1 DNA Way, South San Francisco, CA 94080, USA. ²Department of Protein Chemistry within Research, Genentech, Inc. (a member of the Roche Group), 1 DNA Way, South San Francisco, CA 94080, USA. ${ }^{3}$ Department of Nonclinical Biostatistics within Product Development, Genentech, Inc. (a member of the Roche Group), 1 DNA Way, South San Francisco, CA 94080, USA. ${ }^{4}$ Department of PKPD within Development Sciences, Genentech, Inc. (a member of the Roche Group), DNA Way, South San Francisco, CA 94080, USA. ${ }^{5}$ Department of Bioanalytical Sciences within Development Sciences, Genentech, Inc. (a member of the Roche Group), 1 DNA Way, South San Francisco, CA 94080, USA.

Received: 5 December 2013 Accepted: 13 May 2014 Published: 6 June 2014

\section{References}

1. Thies W, Bleiler L: Alzheimer's disease facts and figures. Alzheimers Dement 2013, 9(2):208-245

2. Sunderland T, Linker G, Mirza N, Putnam KT, Friedman DL, Kimmel LH, Bergeson J, Manetti GJ, Zimmermann M, Tang B, Bartko JJ, Cohen RM: Decreased beta-amyloid1-42 and increased tau levels in cerebrospinal fluid of patients with Alzheimer disease. JAMA 2003, 289(16):2094-2103.

3. Clark CM, Xie S, Chittams J, Ewbank D, Peskind E, Galasko D, Morris JC, McKeel DW Jr, Farlow M, Weitlauf SL, Quinn J, Kaye J, Knopman D, Arai H, Doody RS, DeCarli C, Leight S, Lee VM, Trojanowski JQ: Cerebrospinal fluid tau and beta-amyloid: how well do these biomarkers reflect autopsy-confirmed dementia diagnoses? Arch Neurol 2003, 60(12):1696-1702.

4. Bateman RJ, Xiong C, Benzinger TL, Fagan AM, Goate A, Fox NC, Marcus DS, Cairns NJ, Xie X, Blazey TM, Holtzman DM, Santacruz A, Buckles V, Oliver A, Moulder K, Aisen PS, Ghetti B, Klunk WE, McDade E, Martins RN, Masters CL, Mayeux R, Ringman JM, Rossor MN, Schofield PR, Sperling RA, Salloway S, Morris JC: Clinical and biomarker changes in dominantly inherited Alzheimer's disease. N Engl J Med 2012, 367(9):795-804.

5. Buchhave P, Minthon L, Zetterberg H, Wallin AK, Blennow K, Hansson O: Cerebrospinal fluid levels of beta-amyloid $1-42$, but not of tau, are fully changed already 5 to 10 years before the onset of Alzheimer dementia. Arch Gen Psychiatry 2012, 69(1):98-106.

6. Andreasson U, Vanmechelen $\mathrm{E}$, Shaw LM, Zetterberg $\mathrm{H}$, Vanderstichele $\mathrm{H}$ : Analytical aspects of molecular Alzheimer's disease biomarkers. Biomark Med 2012, 6(4):377-389.

7. Mattsson N, Andreasson U, Persson S, Carrillo MC, Collins S, Chalbot S, Cutler N, Dufour-Rainfray D, Fagan AM, Heegaard NH, Robin Hsiung GY, Hyman B, lqbal K, Lachno DR, Lleó A, Lewczuk P, Molinuevo JL, Parchi P, Regeniter A, Rissman R, Rosenmann H, Sancesario G, Schröder J, Shaw LM,
Teunissen CE, Trojanowski JQ, Vanderstichele H, Vandijck M, Verbeek MM, Zetterberg $\mathrm{H}$, et al: CSF biomarker variability in the Alzheimer's Association quality control program. Alzheimers Dement 2013, 9(3):251-261.

8. Kang JH, Korecka M, Toledo JB, Trojanowski JQ, Shaw LM: Clinical utility and analytical challenges in measurement of cerebrospinal fluid amyloid-beta1-42 and tau proteins as Alzheimer disease biomarkers. Clin Chem 2013, 59(6):903-916.

9. Blennow K, Zetterberg H, Rinne JO, Salloway S, Wei J, Black R, Grundman M, Liu E, AAB-001 201/202 Investigators: Effect of immunotherapy with bapineuzumab on cerebrospinal fluid biomarker levels in patients with mild to moderate Alzheimer disease. Arch Neurol 2012, 69(8):1002-1010.

10. Kroksveen AC, Opsahl JA, Aye T, Ulvik RJ, Berven FS: Proteomics of human cerebrospinal fluid: discovery and verification of biomarker candidates in neurodegenerative diseases using quantitative proteomics. J Proteomics 2011, 74(4):371-388.

11. Fagan $A M$, Perrin $\mathrm{RJ}$ : Upcoming candidate cerebrospinal fluid biomarkers of Alzheimer's disease. Biomark Med 2012, 6(4):455-476.

12. Method of the Year 2012. Nat Methods 2013, 10(1):1

13. Marx V: Targeted proteomics. Nat Methods 2013, 10(1):19-22

14. Gillette MA, Carr SA: Quantitative analysis of peptides and proteins in biomedicine by targeted mass spectrometry. Nat Methods 2013, 10(1):28-34

15. Abdi F, Quinn JF, Jankovic J, McIntosh M, Leverenz JB, Peskind E, Nixon R, Nutt J, Chung K, Zabetian C, Samii A, Lin M, Hattan S, Pan C, Wang Y, Jin J, Zhu D, Li GJ, Liu Y, Waichunas D, Montine TJ, Zhang J: Detection of biomarkers with a multiplex quantitative proteomic platform in cerebrospinal fluid of patients with neurodegenerative disorders. J Alzheimers Dis 2006, 9(3):293-348.

16. Yin GN, Lee HW, Cho JY, Suk K: Neuronal pentraxin receptor in cerebrospinal fluid as a potential biomarker for neurodegenerative diseases. Brain Res 2009, 1265:158-170.

17. Puchades M, Hansson SF, Nilsson CL, Andreasen N, Blennow K, Davidsson P: Proteomic studies of potential cerebrospinal fluid protein markers for Alzheimer's disease. Brain Res Mol Brain Res 2003, 118(1-2):140-146.

18. Finehout EJ, Franck Z, Choe LH, Relkin N, Lee KH: Cerebrospinal fluid proteomic biomarkers for Alzheimer's disease. Ann Neurol 2007, 61(2):120-129.

19. Simonsen AH, McGuire J, Podust VN, Davies H, Minthon L, Skoog I, Andreasen N, Wallin A, Waldemar G, Blennow K: Identification of a novel panel of cerebrospinal fluid biomarkers for Alzheimer's disease. Neurobiol Aging 2008, 29(7):961-968.

20. Hu Y, Malone JP, Fagan AM, Townsend RR, Holtzman DM: Comparative proteomic analysis of intra- and interindividual variation in human cerebrospinal fluid. Mol Cell Proteomics 2005, 4(12):2000-2009.

21. Pan S, Rush J, Peskind ER, Galasko D, Chung K, Quinn J, Jankovic J, Leverenz JB, Zabetian C, Pan C, Wang Y, Oh JH, Gao J, Zhang J, Montine T, Zhang J: Application of targeted quantitative proteomics analysis in human cerebrospinal fluid using a liquid chromatography matrix-assisted laser desorption/ionization time-of-flight tandem mass spectrometer (LC MALDI TOF/TOF) platform. J Proteome Res 2008, 7(2):720-730.

22. Perrin RJ, Craig-Schapiro R, Malone JP, Shah AR, Gilmore P, Davis AE, Roe CM, Peskind ER, Li G, Galasko DR, Clark CM, Quinn JF, Kaye JA, Morris JC, Holtzman DM, Townsend RR, Fagan AM: Identification and validation of novel cerebrospinal fluid biomarkers for staging early Alzheimer's disease. PLoS One 2011, 6(1):e16032

23. Craig-Schapiro R, Perrin RJ, Roe CM, Xiong C, Carter D, Cairns NJ, Mintun MA, Peskind ER, Li G, Galasko DR, Clark CM, Quinn JF, D'Angelo G, Malone JP, Townsend RR, Morris JC, Fagan AM, Holtzman DM: YKL-40: a novel prognostic fluid biomarker for preclinical Alzheimer's disease. Biol Psychiatry 2010, 68(10):903-912.

24. Corder EH, Saunders AM, Strittmatter WJ, Schmechel DE, Gaskell PC, Small GW, Roses AD, Haines JL, Pericak-Vance MA: Gene dose of apolipoprotein E type 4 allele and the risk of Alzheimer's disease in late onset families. Science 1993, 261(5123):921-923.

25. Tarawneh R, Lee JM, Ladenson JH, Morris JC, Holtzman DM: CSF VILIP-1 predicts rates of cognitive decline in early Alzheimer disease. Neurology 2012, 78(10):709-719.

26. Tarawneh R, D'Angelo G, Macy E, Xiong C, Carter D, Cairns NJ, Fagan AM, Head D, Mintun MA, Ladenson JH, Lee JM, Morris JC, Holtzman DM: Visinin-like protein-1: diagnostic and prognostic biomarker in Alzheimer disease. Ann Neurol 2011, 70(2):274-285. 
27. Gerber SA, Rush J, Stemman O, Kirschner MW, Gygi SP: Absolute quantification of proteins and phosphoproteins from cell lysates by tandem MS. Proc Natl Acad Sci U S A 2003, 100(12):6940-6945.

28. Gygi SP, Rist B, Gerber SA, Turecek F, Gelb MH, Aebersold R: Quantitative analysis of complex protein mixtures using isotope-coded affinity tags. Nat Biotechnol 1999, 17(10):994-999.

29. Paweletz CP, Wiener MC, Bondarenko AY, Yates NA, Song Q, Liaw A, Lee AY, Hunt BT, Henle ES, Meng F, Sleph HF, Holahan M, Sankaranarayanan S, Simon AJ, Settlage RE, Sachs JR, Shearman M, Sachs AB, Cook J, Hendrickson RC: Application of an end-to-end biomarker discovery platform to identify target engagement markers in cerebrospinal fluid by high resolution differential mass spectrometry. J Proteome Res 2010, 9(3):1392-1401.

30. Ewers M, Buerger K, Teipel SJ, Scheltens P, Schröder J, Zinkowski RP, Bouwman FH, Schönknecht P, Schoonenboom NS, Andreasen N, Wallin A, DeBernardis JF, Kerkman DJ, Heindl B, Blennow K, Hampel H: Multicenter assessment of CSF-phosphorylated tau for the prediction of conversion of MCl. Neurology 2007, 69(24):2205-2212.

31. Nielsen HM, Minthon L, Londos E, Blennow K, Miranda E, Perez J, Crowther DC, Lomas DA, Janciauskiene SM: Plasma and CSF serpins in Alzheimer disease and dementia with Lewy bodies. Neurology 2007, 69(16):1569-1579.

32. Hansson SF, Andréasson U, Wall M, Skoog I, Andreasen N, Wallin A, Zetterberg H, Blennow K: Reduced levels of amyloid-beta-binding proteins in cerebrospinal fluid from Alzheimer's disease patients. J Alzheimers Dis 2009, 16(2):389-397.

33. Sihlbom C, Davidsson P, Sjögren M, Wahlund LO, Nilsson CL: Structural and quantitative comparison of cerebrospinal fluid glycoproteins in Alzheimer's disease patients and healthy individuals. Neurochem Res 2008, 33(7):1332-1340

34. Ringman JM, Schulman $H$, Becker $C$, Jones T, Bai $Y$, Immermann F, Cole G, Sokolow S, Gylys K, Geschwind DH, Cummings JL, Wan HI: Proteomic changes in cerebrospinal fluid of presymptomatic and affected persons carrying familial Alzheimer disease mutations. Arch Neurol 2012, 69(1):96-104.

35. Craig-Schapiro R, Fagan AM, Holtzman DM: Biomarkers of Alzheimer's disease. Neurobiol Dis 2009, 35(2):128-140.

36. Bayer TA, Paliga K, Weggen S, Wiestler OD, Beyreuther K, Multhaup G: Amyloid precursor-like protein 1 accumulates in neuritic plaques in Alzheimer's disease. Acta Neuropathol 1997, 94(6):519-524.

37. Davidsson P, Westman-Brinkmalm A, Nilsson CL, Lindbjer M, Paulson L, Andreasen N, Sjögren M, Blennow K: Proteome analysis of cerebrospinal fluid proteins in Alzheimer patients. Neuroreport 2002, 13(5):611-615.

38. Carrette O, Demalte I, Scherl A, Yalkinoglu O, Corthals G, Burkhard P, Hochstrasser DF, Sanchez JC: A panel of cerebrospinal fluid potential biomarkers for the diagnosis of Alzheimer's disease. Proteomics 2003, 3(8):1486-1494.

39. Zhang J, Goodlett DR, Quinn JF, Peskind E, Kaye JA, Zhou Y, Pan C, Yi E, Eng J, Wang Q, Aebersold RH, Montine TJ: Quantitative proteomics of cerebrospinal fluid from patients with Alzheimer disease. J Alzheimers Dis 2005, 7(2):125-133. discussion 173-80.

40. Zhang J, Goodlett DR, Peskind ER, Quinn JF, Zhou Y, Wang Q, Pan C, Yi E, Eng J, Aebersold RH, Montine TJ: Quantitative proteomic analysis of age-related changes in human cerebrospinal fluid. Neurobiol Aging 2005, 26(2):207-227.

41. Simonsen AH, McGuire J, Hansson O, Zetterberg H, Podust VN, Davies HA, Waldemar G, Minthon L, Blennow K: Novel panel of cerebrospinal fluid biomarkers for the prediction of progression to Alzheimer dementia in patients with mild cognitive impairment. Arch Neurol 2007, 64(3):366-370.

42. Loeffler DA, DeMaggio AJ, Juneau PL, Brickman CM, Mashour GA, Finkelman JH, Pomara N, LeWitt PA: Ceruloplasmin is increased in cerebrospinal fluid in Alzheimer's disease but not Parkinson's disease. Alzheimer Dis Assoc Disord 1994, 8(3):190-197.

43. Kessler H, Pajonk FG, Meisser P, Schneider-Axmann T, Hoffmann KH, Supprian T, Herrmann W, Obeid R, Multhaup G, Falkai P, Bayer TA: Cerebrospinal fluid diagnostic markers correlate with lower plasma copper and ceruloplasmin in patients with Alzheimer's disease. J Neural Transm 2006, 113(11):1763-1769.

44. Bonneh-Barkay D, Wang G, Starkey A, Hamilton RL, Wiley CA: In vivo CHI3L1 (YKL-40) expression in astrocytes in acute and chronic neurological diseases. J Neuroinflammation 2010, 7:34.

45. Hu WT, Chen-Plotkin A, Arnold SE, Grossman M, Clark CM, Shaw LM, Pickering E, Kuhn M, Chen Y, McCluskey L, Elman L, Karlawish J, Hurtig HI, Siderowf A, Lee VM, Soares H, Trojanowski JQ: Novel CSF biomarkers for
Alzheimer's disease and mild cognitive impairment. Acta Neuropathol 2010, 119(6):669-678.

46. Blennow K, Davidsson P, Wallin A, Ekman R: Chromogranin A in cerebrospinal fluid: a biochemical marker for synaptic degeneration in Alzheimer's disease? Dementia 1995, 6(6):306-311.

47. Craig-Schapiro R, Kuhn M, Xiong C, Pickering EH, Liu J, Misko TP, Perrin RJ, Bales KR, Soares H, Fagan AM, Holtzman DM: Multiplexed immunoassay panel identifies novel CSF biomarkers for Alzheimer's disease diagnosis and prognosis. PLoS One 2011, 6(4):e18850.

48. Wang Y, Hancock AM, Bradner J, Chung KA, Quinn JF, Peskind ER, Galasko D, Jankovic J, Zabetian CP, Kim HM, Leverenz JB, Montine TJ, Ginghina C, Edwards KL, Snapinn KW, Goldstein DS, Shi M, Zhang J: Complement 3 and factor $\mathrm{h}$ in human cerebrospinal fluid in Parkinson's disease, Alzheimer's disease, and multiple-system atrophy. Am J Pathol 2011, 178(4):1509-1516.

49. Finehout $\mathrm{EJ}$, Franck Z, Lee $\mathrm{KH}$ : Complement protein isoforms in CSF as possible biomarkers for neurodegenerative disease. Dis Markers 2005, 21(2):93-101.

50. Hu Y, Hosseini A, Kauwe JS, Gross J, Cairns NJ, Goate AM, Fagan AM, Townsend RR, Holtzman DM: Identification and validation of novel CSF biomarkers for early stages of Alzheimer's disease. Proteomics Clin App 2007, 1(11):1373-1384.

51. Hu WT, Chen-Plotkin A, Arnold SE, Grossman M, Clark CM, Shaw LM, McCluskey L, Elman L, Karlawish J, Hurtig Hl, Siderowf A, Lee VM, Soares H, Trojanowski JQ: Biomarker discovery for Alzheimer's disease, frontotemporal lobar degeneration, and Parkinson's disease. Acta Neuropathol 2010, 120(3):385-399.

52. Meyne F, Gloeckner SF, Ciesielczyk B, Heinemann U, Krasnianski A, Meissner B, Zerr I: Total prion protein levels in the cerebrospinal fluid are reduced in patients with various neurological disorders. J Alzheimers Dis 2009, 17(4):863-873.

53. Jung SM, Lee K, Lee JW, Namkoong H, Kim HK, Kim S, Na HR, Ha SA, Kim JR, Ko J, Kim JW: Both plasma retinol-binding protein and haptoglobin precursor allele 1 in CSF: candidate biomarkers for the progression of normal to mild cognitive impairment to Alzheimer's disease. Neurosci Lett 2008, 436(2):153-157.

54. Suk K: Combined analysis of the glia secretome and the CSF proteome: neuroinflammation and novel biomarkers. Expert Rev Proteomics 2010, 7(2):263-274.

55. Serot JM, Christmann D, Dubost T, Couturier M: Cerebrospinal fluid transthyretin: aging and late onset Alzheimer's disease. J Neurol Neurosurg Psychiatry 1997, 63(4):506-508.

56. Li X, Masliah E, Reixach N, Buxbaum JN: Neuronal production of transthyretin in human and murine Alzheimer's disease: is it protective? J Neurosci 2011, 31(35):12483-12490.

57. Ribeiro CA, Saraiva MJ, Cardoso I: Stability of the transthyretin molecule as a key factor in the interaction with a-beta peptide-relevance in Alzheimer's disease. PLoS One 2012, 7(9):e45368.

58. Lee JM, Blennow K, Andreasen N, Laterza O, Modur V, Olander J, Gao F, Ohlendorf M, Ladenson $\mathrm{JH}$ : The brain injury biomarker VLP-1 is increased in the cerebrospinal fluid of Alzheimer disease patients. Clin Chem 2008, 54(10):1617-1623.

59. Blennow K, Zetterberg H, Minthon L, Lannfelt L, Strid S, Annas P, Basun H, Andreasen N: Longitudinal stability of CSF biomarkers in Alzheimer's disease. Neurosci Lett 2007, 419(1):18-22.

60. Buchhave P, Blennow K, Zetterberg H, Stomrud E, Londos E, Andreasen N, Minthon L, Hansson O: Longitudinal study of CSF biomarkers in patients with Alzheimer's disease. PLoS One 2009, 4(7):e6294.

61. Bouwman FH, van der Flier WM, Schoonenboom NS, van Elk EJ, Kok A Rijmen F, Blankenstein MA, Scheltens P: Longitudinal changes of CSF biomarkers in memory clinic patients. Neurology 2007, 69(10):1006-1011.

62. Höglund K, Bogstedt A, Fabre S, Aziz A, Annas P, Basun H, Minthon L, Lannfelt L, Blennow K, Andreasen N: Longitudinal stability evaluation of biomarkers and their correlation in cerebrospinal fluid and plasma from patients with Alzheimer's disease. J Alzheimers Dis 2012, 32(4):939-947.

63. Le Bastard N, Aerts L, Sleegers K, Martin JJ, Van Broeckhoven C, De Deyn PP, Engelborghs S: Longitudinal stability of cerebrospinal fluid biomarker levels: fulfilled requirement for pharmacodynamic markers in Alzheimer's disease. J Alzheimers Dis 2013, 33(3):807-822.

64. Laird NM, Ware JH: Random-effects models for longitudinal data. Biometrics 1982, 38(4):963-974.

65. Olsson B, Hertze J, Lautner R, Zetterberg H, Nägga K, Höglund K, Basun H, Annas P, Lannfelt L, Andreasen N, Minthon L, Blennow K, Hansson O: Microglial 
markers are elevated in the prodromal phase of Alzheimer's disease and vascular dementia. J Alzheimers Dis 2013, 33(1):45-53.

66. Granger J, Siddiqui J, Copeland S, Remick D: Albumin depletion of human plasma also removes low abundance proteins including the cytokines. Proteomics 2005, 5(18):4713-4718.

67. Ottervald J, Franzén B, Nilsson K, Andersson LI, Khademi M, Eriksson B, Kjellström S, Marko-Varga G, Végvári A, Harris RA, Laurell T, Miliotis T, Matusevicius D, Salter H, Ferm M, Olsson T: Multiple sclerosis: Identification and clinical evaluation of novel CSF biomarkers. J Proteomics 2010 73(6):1117-1132

68. Sunderland T, Wolozin B, Galasko D, Levy J, Dukoff R, Bahro M, Lasser R, Motter R, Lehtimäki T, Seubert P: Longitudinal stability of CSF tau levels in Alzheimer patients. Biol Psychiatry 1999, 46(6):750-755.

69. Seppälä TT, Koivisto AM, Hartikainen P, Helisalmi S, Soininen H, Herukka SK: Longitudinal changes of CSF biomarkers in Alzheimer's disease. J Alzheimers Dis 2011, 25(4):583-594.

70. Fagan AM, Xiong C, Jasielec MS, Bateman RJ, Goate AM, Benzinger TL, Ghetti B, Martins RN, Masters CL, Mayeux R, Ringman JM, Rossor MN, Salloway S, Schofield PR, Sperling RA, Marcus D, Cairns NJ, Buckles VD, Ladenson JH, Morris JC, Holtzman DM, Dominantly Inherited Alzheimer Network: Longitudinal change in CSF biomarkers in autosomal-dominant Alzheimer's disease. Sci Transl Med 2014, 6(226):226ra30.

71. Thinakaran G, Koo EH: Amyloid precursor protein trafficking, processing, and function. J Biol Chem 2008, 283(44):29615-29619.

72. Sakurai T: The role of NrCAM in neural development and disorders-beyond a simple glue in the brain. Mol Cell Neurosci 2012, 49(3):351-363.

73. Bartolomucci A, Pasinetti GM, Salton SR: Granins as disease-biomarkers: translational potential for psychiatric and neurological disorders. Neuroscience 2010, 170(1):289-297.

74. Angelone T, Tota B: Editorial: chromogranin A at the crossroads of health and disease. Curr Med Chem 2012, 19(24):4039-4041.

75. Cho RW, Park JM, Wolff SB, Xu D, Hopf C, Kim JA, Reddy RC, Petralia RS, Perin MS, Linden DJ, Worley PF: mGluR1/5-dependent long-term depression requires the regulated ectodomain cleavage of neuronal pentraxin NPR by TACE. Neuron 2008, 57(6):858-871.

76. Koch SM, Ullian EM: Neuronal pentraxins mediate silent synapse conversion in the developing visual system. J Neurosci 2010, 30(15):5404-5414.

77. Priller C, Bauer T, Mitteregger G, Krebs B, Kretzschmar HA, Herms J: Synapse formation and function is modulated by the amyloid precursor protein. J Neurosci 2006, 26(27):7212-7221.

78. MacLean B, Tomazela DM, Shulman N, Chambers M, Finney GL, Frewen B, Kern R, Tabb DL, Liebler DC, MacCoss MJ: Skyline: an open source document editor for creating and analyzing targeted proteomics experiments. Bioinformatics 2010, 26(7):966-968.

79. Pinheiro J, Bates D, DebRoy S, Sarkar D, R Development Core Team: nlme: Linear and nonlinear mixed effects models. R Pckg V 2010, 3:1-97.

doi:10.1186/1750-1326-9-22

Cite this article as: Wildsmith et al: Identification of longitudinally dynamic biomarkers in Alzheimer's disease cerebrospinal fluid by targeted proteomics. Molecular Neurodegeneration 2014 9:22.

\section{Submit your next manuscript to BioMed Central and take full advantage of:}

- Convenient online submission

- Thorough peer review

- No space constraints or color figure charges

- Immediate publication on acceptance

- Inclusion in PubMed, CAS, Scopus and Google Scholar

- Research which is freely available for redistribution

Submit your manuscript at www.biomedcentral.com/submit
Ciomed Central 